\title{
Uzroci i laboratorijska dijagnostika pleuralnih izljeva u pasa
}

\author{
V. Benko*, I. Šmit, J. Foršek, A. Radonjić, V. Đurić, I. Jović i M. Torti
}

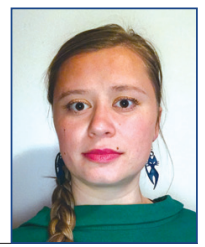

\section{Sažetak}

Pleuralne izljeve definiramo kao patološko nakupljanje tekućine u pleuralnoj šupljini, a koji u pasa nastaju posljedično različitim upalnim, sistemskim, metaboličkim, kardiovaskularnim, infekcijskim i neoplastičnim bolestima te traumama, a dijelimo ih na transudate, modificirane transudate i eksudate. Uzroci pleuralnog izljeva su, patofiziološki gledano, porast hidrostatskog tlaka (pr. posljedično zastojnom zatajivanju srca), pad onkotskog tlaka (pr. posljedično hipoproteinemiji), povećana propustnost stijenke krvnih žila (najčešće posljedično upalnoj reakciji) i opstrukcija limfnih žila (najčešće posljedično tumorskom rastu). Najčešći klinički znak u pasa s patološkim pleuralnim izljevima je otežano disanje (respiratorni distres, dispne-

ja). Ostali klinički znaci uključuju: skvrčen, ležeći položaj s ispruženim glavom i vratom, disanje otvorenim ustima, ubrzano i naglašeno abdominalno disanje, a u uznapredovalih slučajeva prisutna je i cijanoza. Postupkom torakocenteze, osim što uklanjamo pleuralni izljev, možemo ga i uzorkovati, a daljnja laboratorijska dijagnostička obrada je ključna za postavljanje sumnje (ponekad i konačne dijagnoze) na uzrok ili uzroke koji su doveli do patološkog nakupljanja tekućine u pleuralnoj šupljini. Svrha je ovog preglednog rada prikazati uzroke i specifične vrste izljeva u pleuralnu šupljinu u pasa, kao i dijagnostički pristup istima.

Ključne riječi: pleuralni izljevi, pas, uzroci, laboratorijska dijagnostika

\section{Uvod}

Izljev definiramo kao patološko nakupljanje tekućine $u$ tjelesnim šupljinama, do kojeg dolazi posljedično jednoj ili više bolesti, poput trauma, neoplazija, kardiovaskularnih bolesti, metaboličkih poremećaja te infekcijskih i upalnih bolesti. Izljevi se tradicionalno klasificiraju prema koncentraciji ukupnih

proteina i ukupnom broju stanica $\mathrm{s}$ jezgrom (engl. total nucleated cell count, TNCC) (Beatty i Barrs, 2010., Dempsey i Ewing, 2011.). Prema navedenom sustavu klasifikacije razlikujemo sljedeće vrste izljeva (Algoritam 1.): (1) transudate, s koncentracijom ukupnih proteininanižom od $2,5 \mathrm{~g} / \mathrm{dL}$ i TNCC-

Valerija BENKO*, dr. med. vet., (dopisni autor, e-mail: vbenko@vef.hr), Jadranka FORŠEK, dipl. ing. biol., Vlasta ĐURIĆ, mag. med. biochem., dr. sc. Iva ŠMIT, dr. med. vet., docentica, Ines JOVIĆ, dr. med. vet., asistentica, dr. sc. Marin TORTI, dr. med. vet., docent, Veterinarski fakultet Sveučilišta u Zagrebu, Hrvatska; Aleksandra RADONJIĆ, mag. med. biochem., Dom zdravlja Krapinsko-zagorske županije, Klanjec, Hrvatska 


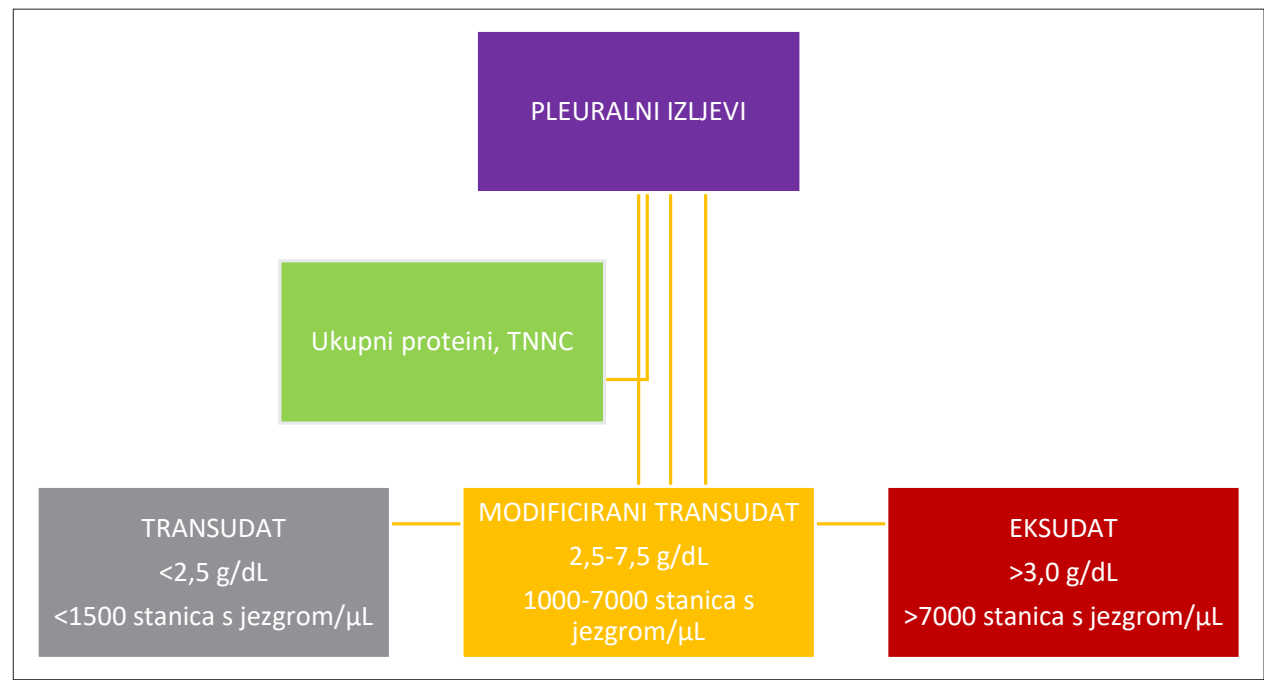

Algoritam 1. Klasifikacija pleuralnih izljeva prema Rizziju (2008.).

om manjim od 1,500 stanica/ $\mu \mathrm{L}$, (2) modificirane transudate, skoncentracijom ukupnih proteinaod 2,5 do $7,5 \mathrm{~g} / \mathrm{dL}$ i TNCC-omod 1,000 do 7,000 stanica/ $\mu \mathrm{L}$ i (3) eksudate, kod kojih je koncentracija ukupnih proteina viša od 3,0 g/dL i TNCC veći od 7,000 stanica/ $\mu \mathrm{L}$ (Rizzi i sur., 2008.). Laboratorijske pretrage izljeva predstavljaju dijagnostički postupak kojim se može posumnjati na proces koji je doveo do patološkog nakupljanja tekućine u tjelesnoj šupljini (Alleman, 2003.). Tako Dempsey i Ewing (2011.) modificirano klasificiraju izljeve prema mogućem uzroku na: (1) transudate siromašne proteinima, (2) transudate bogate proteinima, (3) septičke eksudate, (4) neseptičke eksudate, (5) izljeve podrijetlom od rupturiranih krvnih žila i visceralnih organa (hemoragijski, limforagijski ili hilozni izljevi, uroperitoneum i bilijarni peritonitis) i (6) izljeve nastale posljedično ljuštenjem stanica.

Većinu izljeva vlasnici kućnih ljubimaca ne primjećuju dok ne počnu pokazivati značajne kliničke znakove. Psi i mačke s patološkim pleuralnim izljevima često pokazuju otežano disanje (respiratorni distres, dispneju) kao najčešći klinički znak (Fossum, 2005., Nelson, 2005.). Ostali klinički znaci uključuju: skvrčen, ležeći položaj s ispruženom glavom i vratom, disanje otvorenih ustiju, ubrzano i naglašeno abdominalno disanje, a kod uznapredovalih slučajeva prisutna je i cijanoza. Kod blažih izljeva, letargija i nepodnošenje tjelesnog napora često su jedini klinički znaci. Klinički znaci često znaju biti nespecifični pa tako i kašalj može biti jedini znak u pasa i mačaka s kroničnim pleuralnim izljevom. Klinički nalaz koji prati pleuralne izljeve ovisi o količini izljeva, a uključuju muklije srčane tonove, tiši dišni šum, a može se pojaviti i proširenje jugularnih vena (Nelson, 2005.). Svrha je ovog preglednog rada prikazati uzroke i specifične vrste izljeva u pleuralnu šupljinu u pasa, kao i dijagnostički pristup istima.

\section{Etiopatogeneza pleuralnih izljeva}

Pleuralna šupljina je prostor kojeg tvore visceralna i parijetalna pleura, a medijastinum je dijeli na lijevu i desnu 
šupljinu. Do danas se sa sigurnošću ne zna komuniciraju li lijeva i desna pleuralna šupljina u pasa i mačaka ili se radi o dvije fizički odvojene šupljine (Evans, 1993.). Mala količina tekućine u pleuralnoj šupljini u zdravih životinja prisutna je normalno; tekućina omogućava minimalno trenje listova pleure tijekom disanja. Normalna se količina tekućine $\mathrm{u}$ pleuralnoj šupljini $\mathrm{u}$ pasa i mačaka kreće od 0,1 do 0,3 mL/kg tjelesne mase (Miserocchi i sur., 1984.). Starlingove sile, kojima je određen protok tekućine kroz kapilarnu stijenku, važne su i za protjecanje tekućine unutar i izvan pleuralnog prostora (Nelson, 2005.).

Ukoliko se u pleuralnoj šupljini nakuplja slobodna tekućina govorimo o pleuralnom izljevu. Čimbenici koji dovode do nakupljanja tekućine u pleuralnoj šupljini su trojaki te razlikujemo (1) čimbenike koji mijenjaju ravnotežu transpleuralnog tlaka, (2) čimbenike koji otežavaju limfnu drenažu i (3) čimbenike koji povećavaju mezotelnu i kapilarnu endotelnu propusnost (Zocchi, 2002.).

Patofiziološki mehanizmi odgovorni za nakupljanje tekućine $u$ pleuralnoj šupljini su: (1) porast hidrostatskog tlaka (kao što je to slučaj kod zastojnog zatajivanja srca), (2) pad onkotskog tlaka (najčešće kod hipoproteinemija), povećana propustnost stijenke krvnih žila (najčešće posljedično upalnoj reakciji) i (4) opstrukcija limfnih žila (najčešće posljedično tumorskom rastu) (López i Martinson, 2017.). Od specifičnih uzroka pleuralnih izljeva (Tabela 1.), najčešće govorimo o modificiranim transudatima prouzročenim bolešću srca, transudatima prouzročenim hipoproteinemijom (hipoalbuminemijom), traumatskom hemotoraksu, hemotoraksu posljedičnom prirođenim ili stečenim koagulopatijama, tumorskom rastu ili torziji plućnog režnja; do pojave hilotoraksa dovode gljivične infekcije, kardiopulmonalna dirofilarioza, tromboza kranijalne šuplje vene i prirođene grješke $\mathrm{u}$ građi glavnog mlječovoda (Nelson i Couto, 2014.). Ipak, u većini slučajeva hilotoraksa u pasa radi se o idiopatskom hilotoraksu. Pozitivnom kontrastnom limfangiografijom $u$ pasa i mačaka s hilotoraksom prikazuje se izražena limfangiektazija medijastinalnih i pleuralnih limfnih žila (Birchard i sur., 1995.). Na temelju citološke pretrage se hilozni izljevi obično lako mogu razlikovati od pseudohiloznih izljeva, no ipak je uputno odrediti koncentracije triglicerida i kolesterola u krvnom serumu i izljevu za definitivno razlikovanje (Tyler i Cowell, 1989.).

U pasa najčešći tumori koji dovode do pojave pleuralnog izljeva su limfomi (Slika 1.), karcinomi i adenokarcinomi, dok sarkomi i mezoteliomi rijetko dovode do pojave pleuralnog izljeva (Thompson i Rebar, 2016). Pleuralne izljeve, kao što smo već i prije naveli, klasificiramo kao transudate, modificirane transudate i eksudate, koje dodatno možemo podijeliti na hemoragijske, hilozne, bilijarne, septične i aseptične (Epstein, 2014.).

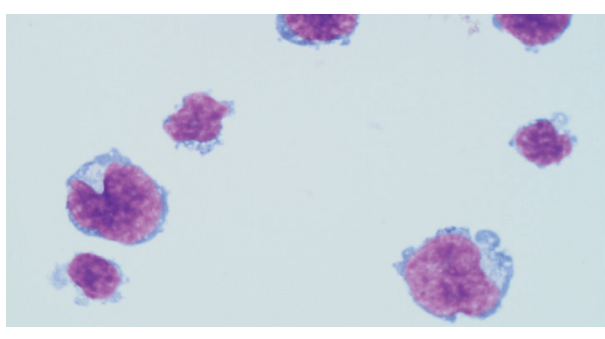

Slika 1. Neoplastični pleuralni izljev limfom IlMay-Grunwald-Giemsa bojanje, x 1000 povećanje, izvor: arhiva Hematološkog laboratorija Klinike za unutarnje bolesti).

Na pleuralni izljev klinički možemo posumnjati u pasa koji ubrzano i plitko dišu, zauzimaju ortopnoičan stav, a perkusijom pluća dobivamo mukli zvuk, dok auskultacijski nad plućima i srcem čujemo stišan dišni šum i mukle srčane tonove. Konačnu dijagnozu pleuralnog izljeva postavljamo na temelju 
Tabela 1. Uzroci izljeva (prema O’Brien i Lumsden, 1988., Stockam i Scott, 2008.).

\begin{tabular}{|c|c|c|}
\hline VRSTE IZLJEVA & $\begin{array}{l}\text { PODVRSTE } \\
\text { IZLJEVA }\end{array}$ & UZROCI \\
\hline Transudati & $\begin{array}{l}\text { bogati } \\
\text { proteinima }\end{array}$ & $\begin{array}{l}\text { a) povećan intravaskularnihidrostatski tlak } \\
\text { b) kongestivno zatajenje srca } \\
\text { c) postsinusoidna portalna hipertenzija }\end{array}$ \\
\hline \multirow{3}{*}{ Eksudati } & $\begin{array}{l}\text { siromašni } \\
\text { proteinima }\end{array}$ & $\begin{array}{l}\text { a) hipoalbuminemija } \\
\text { b) ciroza } \\
\text { c) limfatična opstrukcija } \\
\text { d) necirotična portalna hipertenzija }\end{array}$ \\
\hline & septični & $\begin{array}{l}\text { a) sekundarna upala zbog endogenih ili egzogenih } \\
\text { stranih substanci ili imunokompleksa } \\
\text { b) penetrirajuće rane } \\
\text { c) propuštanje gastrointestinalnog trakta } \\
\text { d) migrirajuće strano tijelo } \\
\text { e) transplacentarne infekcije sekundarno zbog } \\
\text { maternalnebakterijemije } \\
\text { f) bakterijske translokacije iz pluća } \\
\text { g) hipoperfuzija gastrointestinalnog tkiva } \\
\text { h) hematogeno širenje infekcije iz udaljenih mjesta } \\
\text { i) ruptura ili infekcija urogenitalnog trakta }\end{array}$ \\
\hline & Neseptični & $\begin{array}{l}\text { a) pankreatitis } \\
\text { b) FIP }\end{array}$ \\
\hline $\begin{array}{l}\text { Izljevi prouzročeni } \\
\text { rupturom žila ili } \\
\text { visceralnih organa }\end{array}$ & & $\begin{array}{l}\text { a) hemoragijski izljevi } \\
\text { b) hilozni izljevi } \\
\text { c) Bartonella spp. povezani izljevi } \\
\text { d) uroabdomen } \\
\text { e) bilijarni peritonitis }\end{array}$ \\
\hline $\begin{array}{l}\text { Izljevi prouzročeni } \\
\text { ljuštenjem stanica }\end{array}$ & & $\begin{array}{l}\text { a) neoplazija } \\
\text { b) proliferacija reaktivnog mezotela }\end{array}$ \\
\hline
\end{tabular}

rentgenografske ili ultrazvučne pretrage prsne šupljine.

Uzorak pleuralnog izljeva, kao i potpunu evakuaciju izljeva postižemo provodeći postupak torakocenteze. Sam je postupak torakocenteze dobro provoditi uz ultrazvučnu kontrolu, naravno ukoliko je to moguće. Sedacija je preporučljiva, jer njome umanjujemo stres pacijenta. Pacijenta postavljamo u sternalni ili lateralni, bočni položaj vodeći računa da mu manipulacijom i fiksacijom dodatno ne otežamo disanje. Nakon pripreme područja punkcije šišanjem i brijanjem, mjesto višekratno dezinficiramo naizmjenično alkoholom i otopinom klorheksidina ili povidonjodida. Moguće je aplicirati i lokalni anestetik (najčešće lidokain), iako zahvat nije osobito bolan. Pogodno mjesto punkcije je od osmog do sedmog međurebrenog prostora, otprilike u donjoj trećini prsne šupljine. Kako punkcijom pleuralne šupljine možemo izazvati jatrogeni pneumotoraks treba uvijek raditi s tzv. zatvorenim sustavom (najčešće primjenom trokrake skretnice), odnosno treba spriječiti prodor zraka u pleuralnu šupljinu. Stijenku pleuralne šupljine probadamo uvijek uz kranijalni 
rub rebara da ne bismo oštetili krvne žile i živce koji leže kaudalno. Nakon uzimanja uzoraka torakocentezu nastavljamo sve dok ne evakuiramo što je više moguće tekućine (iznimka je hemotoraks). Nakon izvlačenja igle mjesto punkcije ponovno višekratno dezinficiramo (Alleman, 2003.).

\section{Laboratorijska pretraga pleuralnog izljeva}

Laboratorijska analiza izljeva preporuča se kao pomoćni alat u određivanju uzroka izljeva. Tekućina izljeva može se skupljati u epruvete s EDTA antikoagulansom (ljubičasti čep), serumske epruvete (žuti ili crveni čep), sterilne epruvete za mikrobiološku pretragu te $u$ druge epruvete za specifične testove (poput, lančane reakcije polimerazom - PCR pretrage). Uzorak izljeva koji je prikupljen u epruvetu s EDTA antikoagulansom najčešće koristimo kako bismo odredili TNCC i hematokrit (kod hemoragijskih izljeva, odnosno hemotoraksa) na automatiziranim hematološkim brojačima. TNCC određujemo u izljevu jer može sadržavati leukocite, mezotelne stanice i potencijalno, druge stanice $s$ jezgrom.

Rutinski se, u smislu biokemijskih pretraga izljeva, provodi određivanje koncentracije ukupnih proteina (TP), dok se koncentracija ureje, kreatinina, elektrolita, triglicerida, kolesterola, bilirubina i drugih analita određuju $u$ slučaju sumnje na specifične uzroke (pr. kod rupture mokraćnog mjehura, hiloznih izljeva, rupture žučnog mjehura itd.).

U slučaju crvenkasto obojenih izljeva uputno je odrediti hematokrit ili ukupan broj eritrocita, pritom ih uspoređujući s vrijednostima hematokrita i ukupnog broja eritrocita $u$ perifernoj krvi. Na navedeni način procjenjujemo radi li se o pravom hemoragijskom izljevu. Kada je krvarenje glavni uzrok pojave izljeva, hematokrit i broj eritrociti u izljevu mogu biti slični vrijednostima u perifernoj krvi. Ubrzo nakon krvarenja u tjelesne šupljine, zbog resorpcije putem limfnih žila ili promjenjenog gradijenta onkotskog tlaka koji potiče gibanje tekućine iz intersticija u tjelesnu šupljinu, broj eritrocita počinje opadati (Stockham i Scott, 2008.).

Unutar 30 minuta od uzorkovanja izljeva izrađuju se razmazi, izravno i/ili iz resuspendiranog sedimenta centrifugiranog izljeva (ovisno o samom izgledu, broju stanica i gustoći izljeva). Metode pripreme razmazaka ovise o samoj staničnosti izljeva. Preporuča se što je prije moguće kako bi se izbjegle in vitro promjene (proliferacija mikroorganizama, promjene na stanicama ili in vitro fagocitoza) načiniti direktni razmazak i tzv. razmazak s koncentracijskom linijom. U slučaju niskog TNCC-a potrebno je centrifugirati izljev te načiniti razmaske iz sedimenta. Preparat se najčešće boji May-GrünwaldGiemsinom metodom. Nakon bojenja i sušenja, preparat pregledavamo pod mikroskopom na povećanjima x 40, x 100, x 200, x 400 i pod imerzijskim povećanjem $\mathrm{x} 1000$.

\section{Stanice u pleuralnom izljevu}

Stanice koje rutinski nalazimo u izljevima su neutrofili, limfociti, mezotelne stanice, makrofagi, eritrociti i trombociti, dok eozinofile, mastocite i neoplastične stanice nalazimo nešto rjeđe. Općenito govoreći, povećani broj neutrofila $\mathrm{u}$ izljevu upućuje na upalni proces koji može biti primarni uzrok izljeva ili se pak javlja sekundarno, primjerice posljedično nekrozi tumorskog procesa. Upalni izljevi najčešće pripadaju eksudatima (Algoritam 1.). Nedegenerativni neutrofili, tj. neutrofili koji morfološki izgledaju kao i u razmascima periferne krvi često ukazuju na izljev nebakterijskog uzroka. Degenerativno promjenjeni neutrofili sadrže nabubrenu i svijetlo obojanu jezgru, nedostatak jezgrinog 
kromatinskog uzorka i varijabilan stupanj citoplazmatske vakuolizacije i najčešće ukazuju na postojanje bakterijske upale (Slike 2. i 3.).

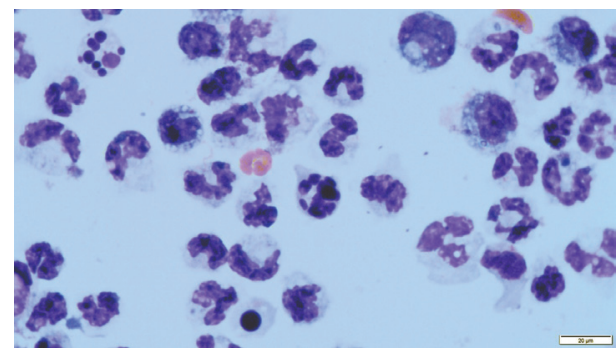

Slika 2. Eksudat - dominantni nalaz neutrofila (May-Grunwald-Giemsa bojanje, x 1000 povećanje, izvor: arhiva Hematološkog laboratorija Klinike za unutarnje bolesti).

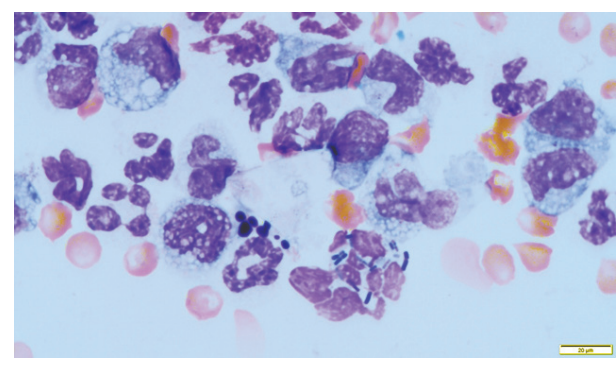

Slika 3. Gnojni pleuralni izljev. U razmasku nalazimo mnoštvo neutrofilnih granulocita $s$ unutarstanično smještenim bakterijama (MayGrunwald-Giemsa bojanje, x 1000 povećanje, izvor: arhiva Hematološkog laboratorija Klinike za unutarnje bolesti).

Limfociti se kod većine izljeva pa tako i kod pleuralnih izljeva, pojavljuju kao mali limfociti koji sadrže malu okruglu jezgru (promjera manjeg $10 \mu \mathrm{m}$ ), čvrsti kromatin i malu količinu bazofilne citoplazme. Kada su limfociti stimulirani, mogu pokazivati citološke karakteristike reaktivnih limfocita, plazmacitoidnih limfocita ili plazma stanica. Neoplastični limfociti sadrže jezgru promjera većegod $10 \mu \mathrm{m}$, fino granulirani do homogeni kromatin s prominetnim ili velikim jezgricama te izraženom bazofilnom citoplazmom (Stockham i Scott, 2008.). Limfociti se često nalaze $u$ izljevima $i$ dominantna su populacija stanica kod hiloznih izljeva i kod neoplastičnih izljeva prouzročenih limfomima (Slika 1.) (Rizzi i sur., 2008.).

Makrofagi su velike mononuklearne stanice s obilnom sivom do svijetloplavom citoplazmom i okruglom do bubrežastom jezgrom. Često sadrže vakuole i fagocitirani sadržaj (npr. Fagocitiranje neutrofila, hemosiderina, hematoidinskih kristala i eritrocita - $\mathrm{zv}$. eritrofagocitoza kod hemoragijskih izljeva, slika 4.) te ih po tome razlikujemo od drugih stanica.

Mezotelne stanice oblažu pleuralnu, abdominalnu i perikardijalnu šupljinu. Dolaze pojedinačno ili u nakupinama. Sadrže umjereno veliku količinu i srednje bazofilno obojanu citoplazmu, a ponekad u citoplazmi sadrže i mjehuriće. Hiperplastične i reaktivno podražene mezotelne stanice sadrže izraženo bazofilnu citoplazmu, ponekad ružičastog i resastog ruba (Slika 5.) (Thompson i Rebar, 2016.). Mezotelne stanice su u mnogim izljevima prisutne $u$ različitom broju. Važno je napomenuti da pri upalnim stanjima, mezotelne stanice postaju aktivne, reaktivne ili hiperplastične. Osim u pojedinačnim formama, mezotelne stanice mogu dolaziti u grupama te katkad i u trodimenzionalnim okruglastim oblicima. Reaktivne mezotelne stanice po svojim morfološkim ka-

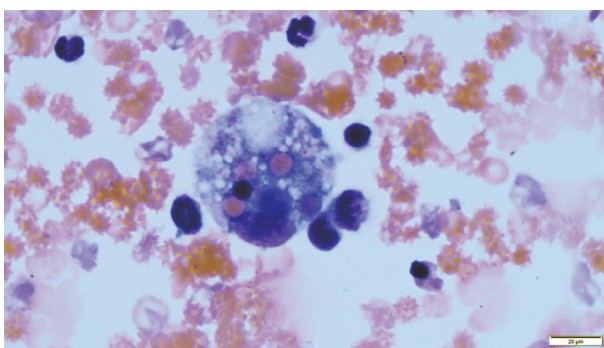

Slika 4. Makrofag s eritrofagocitozom (MayGrunwald-Giemsa bojanje, x 1000 povećanje, izvor: arhiva Hematološkog laboratorija Klinike za unutarnje bolesti). 
rakteristikama mogu oponašati izgled malignih neoplastičnih stanica što kod neiskusnog dijagnostičara može prouzročiti lažno interpretiranje nalaza i proglašenje lažnog malignog stanja (Rizzi i sur., 2008.).

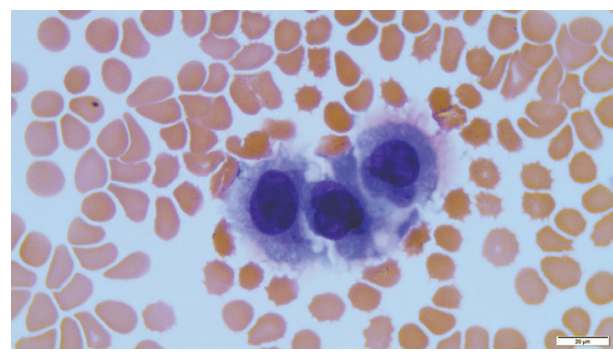

Slika 5. Mezotelne stanice (May-GrunwaldGiemsa bojanje, x 1000 povećanje, izvor: arhiva Hematološkog laboratorija Klinike za unutarnje bolesti).

\section{Hemoragijski pleuralni izljevi}

U veterinarskoj medicini još uvijek ne postoji standardna definicija hemoragijskog pleuralnog izljeva, ponajprije zbog činjenice da je hematokrit izljeva ovisan o hematokritu periferne krvi. Ipak, hemoragijskim pleuralnim izljevom (hemotoraks) smatramo pleuralni izljev s hematokritom koji iznosi barem $25 \%$ hematokrita periferne krvi (Prittie i Barton, 2004.).

Hemoragijski izljevi mogu biti rezultat rupture krvnih žila ili promjeni integriteta vaskularnog endotela koji je inače održan međudjelovanjem trombocita i čimbenika grušanja krvi ( $\mathrm{O}^{\prime} B$ rien i Lumsden, 1988.). Hemoragijske izljeve potrebno je razlikovati od jatrogene krvne kontaminacije do koje može doći tijekom izvođenja torakocenteze. Nekoliko čimbenika može pomoći kod razlikovanja ova dva procesa, no perakutno krvarenje unutar 45 minuta nije moguće razlikovati od jatrogene krvne kontaminacije. Jedan od razlikovnih čimbenika je najčešće nedostatak trombocita $\mathrm{u}$ hemoragijskom izljevu, a hemoragijski izljev i ne gruša
(Forrester i sur., 1988.). Dodatno, pravi hemoragijski izljev može sadržavati reaktivne makrofage $s$ fagocitiranim eritrocitima te hemosiderin ili hematoidin (Slika 4.) (Tyler i Cowell, 1989.).

Mnogobrojni su uzroci nastanka hemoragijskih pleuralnih izljeva, a najčešći uzrok je trauma (tupa, oštra ili jatrogena). Anamnestički podatci govore o nedavnom udaru prometnog vozila u životinju, torakocentezi, torakotomiji/ torakoskopiji, intratorakalnoj punkciji iglom i sl. Osim navedenih uzroka do pojave hemoragijskih pleuralnih izljeva dovode i tumori, koagulopatije, torzija plućnog režnja ili infekcija. Poremećaji primarne ili sekundarne hemostaze mogu prouzročiti hemoragijske pleuralne izljeve, a najčešći je uzrok u praksi trovanje rodenticidnim antikoagulansima (Epstein, 2014.).

U literaturi su opisani i specifični uzroci hemoragijskog pleuralnog izljeva: hemangiosarkom (Nakamura i sur., 2008., Rutherfor i sur., 2016.) mezoteliom, metastaski karcinom jajnika, osteosarkom, karcinom pluća (Nakamura i sur., 2008.), infekcija vrstama Spirocerca lupi i Dirofilaria immitis te pankreatitis (Slensky, 2009.).

\section{Gnojni pleuralni izljevi}

Gnojni pleuralni izljev (piotoraks) definiramo kao prisutnost septičkog izljeva u pleuralnoj šupljini. Prouzročen je bakterijskim pleuritisom s posljedičnim nakupljanjem hemopurulentne tekućine u pleuralnoj šupljini. U citološkoj slici gnojnog pleuralnog izljeva dominira veći broj, često degenerativno promijenjenih, neutrofilnih granulocita s unutarstanično i izvanstanično smještenim bakterijama (Bauer i Woodfield, 1995.). Neutrofilni granulociti pokazuju znakove kariolize (nabubren i blijed izgled jezgri) i kariorekse (fragmentirana jezgra), a prisutstvo kariolitičnih neutrofilnih granulocita pobuđuje sumnju da se radi 
o septičnom procesu (Baker i Lumsden, 2000.). U dijagnostičkom smislu važno je potvrditi nalaz unutarstanično smještenih bakterija. Naime, nalazimo li bakterije samo izvanstanično može se raditi o kontaminaciji bakterijama unutar samog uzorka ili kontaminaciji tijekom bojanja preparata. Bakteriološka pretraga s izolacijom uzročnika kao i određivanje osjetljivosti izoliranog uzročnika na antibakterijske lijekove dio su klasične obrade gnojnog pleuralnog izljeva (Bauer i Woodfield, 1995.).

Mogući su uzroci gnojnog pleuralnog izljeva migracija stranog tijela, penetrirajuće ugrizne rane, migracije parazita, nedavna torakocenteza ili nedavni kirurški zahvat u pleuralnoj šupljini, uznapredovali slučajevi diskospondilitisa i apscedirajući tumori $\mathrm{u}$ pleuralnoj šupljini (Demetriou i sur., 2002., Schultz i Zwingenberger, 2008., Boothe i sur., 2010.). Opisana je i pasminska predispozicija za razvoj gnojnog pleuralnog izljeva pa su tako najzahvaćenije pasmine engleski koker španijeli, graničarski koliji i njihovi križanci te labradorski retriveri. U slučaju labradorskih retrivera stanje je češće opisivano u mužjaka, prosječne životne dobi od četiri godine (Demetriou i sur., 2002.).

Postavljanje dijagnoze gnojnog pleuralnog izljeva uglavnom je jednostavno i temelji se na kliničkim znacima, slikovnoj dijagnostici (rentgenografija, ultrazvuk), laboratorijskoj i citološkoj pretrazi izljeva te nalazu bakteriološke pretrage (Tabela 2.) (Fossum, 2000.).

Prognoza je varijabilna, no uz agresivno liječenje može biti dobra (Rooney i Monnet, 2002., Barrs i sur., 2005., Johnson i Martin, 2007.). Tako u pasa s izrazitim respiratornim distresom, razvijenim sindromom sustavnog upalnog odgovora ili sepsom prognoza je lošija u odnosu na ostale pse. Epstein (2014.) navodi da preživljavanje u pasa s gnojnim pleuralnim izljevom iznosi
$83 \%$, dok se u do $14 \%$ slučajeva gnojni pleuralni izljev nakon završetka liječenja može ponovno javiti (Rooney i Monnet, 2002., Barrs i sur., 2005., Johnson i Martin, 2007.). U slučajevima rekurentnih izljeva $71 \%$ pasa je bilo uspavano, odnosno uginulo (Boothe i sur., 2010.). Infekcija vrstama Nocardia i Actinomyces je jedan od čimbenika rizika za ponovnu pojavu gnojnog pleuralnog izljeva (Piek i Robben, 2000.).

Tabela 2. Najčešći bakterijski uzročnici gnojnog pleuralnog izljeva u pasa (prema Jang i sur., 1997.,Walker i sur., 2000.)

\begin{tabular}{l|l|}
\hline $\begin{array}{l}\text { Anaerobne } \\
\text { bakterije }\end{array}$ & Aerobne bakterije \\
\hline $\begin{array}{l}\text { Bacterioides spp. } \\
\text { Clostridium spp. }\end{array}$ & Actinomyces spp. \\
\hline $\begin{array}{l}\text { Eubacterium spp. } \\
\text { Fusobacterium spp. }\end{array}$ & Enterobacter spp. \\
\hline $\begin{array}{l}\text { Peptostreptococcus } \\
\text { spp. }\end{array}$ & Mycoplasma spp. \\
\hline $\begin{array}{l}\text { Porphyromonas } \\
\text { spp. }\end{array}$ & Nocardia spp. \\
\hline $\begin{array}{l}\text { Prevotella spp. } \\
\text { Propionebacterium } \\
\text { spp. }\end{array}$ & Pasteurella spp. \\
\hline
\end{tabular}

\section{Nokardijski i aktinomicetični izljevi}

Bakterije Nocardia asteroides i Actinomyces spp. važan su uzrok nastanka pleuralnih (ali i peritonealnih) izljeva kod pasa i mačaka. Makroskopski su ovi izljevi mutni, žute do crvene boje, koji svojim izgledom podsjećaju na juhu od rajčica. Tipično, takvi izljevi sadrže vidljive partikule ili granule nazvane sumpornim granulama. Obzirom na vrstu izljevi posljedično nokardijskoj/aktinomicetičnoj infekciji pripadaju eksudatima, nalazimo visoku koncentraciju 
ukupnih proteina i izrazito visoki broj stanica. Mikroskopski je vidljiva neutrofilna ili miješana upala, no tip upale ovisi o dužini trajanja procesa. S obzirom da kod većine septičnih izljeva tipično nalazimo degenerativno promijenjene neutrofilne granulocite, kod nokardijskih i aktinomicetičnih izljeva mikroskopska slika je obrnuta: većina neutrofilnih granulocita nije degenerativno promijenjena te ne pokazuju znakove starenja (hipersegmentacija) i apoptoze (piknoza, karioreksa). Degenerirani neutrofilni granulociti uglavnom se nalaze samo u blizini bakterijskih kolonija. Morfologija je ovih bakterijskih vrsta vrlo specifična, te se na razmascima njihove kolonije često mogu naći na rubovima, kao niti koje se granaju. Citološki nije moguće razlikovati ove dvije bakterijske vrste (Thompson i Rebar, 2016.). Međutim, vrsta Nocardia varijabilno raste u kiselom mediju, dok vrsta Actinomyces ne raste $\mathrm{u}$ kiselom mediju (Songer i Post, 2005.). Nadalje, sumporne granule češće nalazimo kod aktinomicetičnih infekcija, a rjeđe kod nokardioze (Sykes, 2012.). Zbog navedenog se kod citološkog nalaza nitastih bakterija obvezno mora učiniti bakteriološka pretraga izljeva ili sumpornih granula (Thompson i Rebar, 2016.).

\section{Bilijarni pleuralni izljevi}

Većina bilijarnih pleuralnih izljeva (tzv. bilotoraksa ili koletoraksa) u pasa i mačaka opisana je $s$ istovremenim bilijarnim peritonealnim izljevom, a najčešće se uzrokom pojave ovakvog tipa izljeva smatra trauma (Bellenger i sur., 1975., Murgia, 2013.). U zabilježenih slučajeva bilijarnih pleuralnih izljeva radilo se o prostrijelnoj rani $\mathrm{s}$ posljedičnom rupturom žučnog mjehura i istjecanjem žuči u prsnu šupljinu kroz oštećeni ošit (Bellenger i sur., 1975.).

U ljudi se bilijarni pleuralni izljev javlja rijetko i to najčešće kao komplikacija bilijarnog peritonitisa. Postavljanje dijagnoze je otežano jer je klinička slika nespecifična (Basu i sur., 2010.).

Guillaumin i sur. (2006.) opisuju slučaj deset godina stare pirenejske ovčarke s bilijarnim pleuralnimizljevom nastalim kao komplikacijom kolecistetomije. Prema tome, pojava pleuralnog izljeva jedna je od mogućih (iako rijetkih) komplikacija kirurškog zahvata na žučnom mjehuru, posebice u slučajevima kada je došlo do izlijevanja žuči u trbušnu šupljinu.

Pojava bilijarnog pleuralnog izljeva u navedenog psa nije $u$ potpunosti objašnjena, no mogući mehanizam nastanka je prijenos putem dijafragmatičnih limfnih žila (Noone, 1985., Barnhart i Rasmussen, 1996.). Nadalje, opisani subdijafragmatični uzroci pleuralnih izljeva u ljudi ali i životinja su pankreatitis (Uchikov i sur., 2000., Namazi i Mowla, 2004.) i hepatopatije, uključujući i cirozu jetre (Hoofnagle i sur., 1997., Kristal i sur., 2004.). Uzrokom bilijarnog pleuralnog izljeva može biti i rijetka biliopleuralna fistula, opisana u pasa s penetrirajućim ozljedama prsne šupljine (Bellenger i sur., 1975., Davis i Spaulding, 2004.).

\section{Hilozni pleuralni izljevi}

Hilozni pleuralni izljev (hilotoraks) definiramo kao nakupljanje limfe $u$ pleuralnoj šupljini posljedično smanjenoj ili prekinutnoj limfatičnoj drenaži. Najvažnija je limfatična žila u pleuralnoj šupljini prsni limfni vod (mlječovod) koji započinje proširenjem (sabirna cisterna, cisterna chyli) i koji prihvaća limfu iz crijeva, jetre i kaudalnih dijelova tijela (Bezuidenhout, 1993.). Tipično pritječe venskom sustavu na mjestu gdje se sastaju unutarnja i vanjska jugularna vena (Epstein, 2014.).

Hilozni izljevi sadrže limfnu tekućinu bogatu hilomikronima koja se inače nalazi u limfatičnim žilama i propuštena je kroz probavni sustav te kao takva prolazi kroz prsni limfni 
vod. Hilomikroni su lipoproteini bogati trigliceridima apsorbirani iz crijeva nakon probavljanja hrane koja sadrži masti. Limfatične žile koje se nalaze kranijalno iznad ošita ne sadrže limfu. Hilozni izljevi u pasa i mačaka najčešće se pojavljuju kao bilateralni pleuralni izljevi (Meadows i Macwilliams, 1994.). Limfa normalno prolazi iz prsnog limfnog voda u venski sustav. Fizička opstrukcija prsnog limfnog voda često je rezultat tumorskog rasta, granuloma ili upale $\mathrm{u}$ području medijastinuma, a koji pritišću prsni limfni vod ili okolne krvne žile (Meadows i Macwilliams, 1994., Mertens i Fossum, 2002.). Bolesti limfatičnih žila, povećani venski hidrostatski tlak $\mathrm{u}$ razini desnog dijela srca, izmijenjena pozicija organa, tumori ili idiopatski uzorci dovode do pojave hiloznog pleuralnog izljeva (Hodges i sur., 1993.).

U pasa mogući uzrok hiloznog pleuralnog izljeva je ozljeda prsnog limfnog voda, traumatske ili upalne prirode (Carobbi i sur., 2008., da Silva i Monnet, 2011., Mayhew i sur., 2012.). Kada govorimo o idiopatskom hiloznom pleuralnom izljevu želimo naglasiti da unatoč širokoj obradi uzrok pojave izljeva nije razjašnjen (Singh i sur., 2012.).

Hilozni se pleuralni izljev može pojaviti u bilo koje pasmine pasa ili mačaka, no u afganistanskih hrtova on se zbog sklonosti pasmine k torziji plućnog režnja češće javlja (Fossum i sur., 1986., Neath i sur., 2000.).

Klasično se hilozni izljev opisuje kao izljev mliječno bijele boje, no boja može varirati od prozirne preko mliječno bijele pa sve do žućkaste ili ružičaste. Pseudohilozni izljevi su mliječne boje, ali ne sadrže limfu, dakle nisu bogati hilomikronima i trigliceridima, već ta mliječno bijela boja potječe od tvari podrijetlom od staničnog raspada, lecitinskog globulinskog kompleksa i kolesterola (Meadows i Macwilliams, 1994., Fossum, 2005.).
Hilozne izljeve se definitivno prepoznaje na temelju određivanja koncentracije triglicerida $\mathrm{u}$ izljevu te krvnom serumu; u slučajevima hiloznih izljeva koncentracija triglicerida $u$ izljevu je viša od serumske koncentracije (Meadows i Macwilliams, 1994., Mertens i Fossum, 2002., Fossum, 2005.).

\section{Maligni pleuralni izljevi}

Malignomi mogu biti uzrokom pojave pleuralnog izljeva, a mogući mehanizmi koje dovode do nakupljanja slobodne tekućine u pleuralnoj šupljini posljedično tumorskom rastu su: (1) zahvaćenost pleuralne površine tumorom, s povećanom permeabilnošću pleuralne ovojnice (utjecaj vaskularnog endotelnog čimbenika rasta) (Cheng i sur., 1999.), (2) opstrukcija limfnih žila i vena tumorom, (3) opstrukcija bronha endobronhijalnim tumorom s posljedičnom atelektazom pluća i sniženja pleuralnog tlaka, (4) parapneumonični mehanizam izljeva i (5) malignomom uzrokovano puknućne prsnog limfnog voda. Maligni pleuralni izljevi u ljudi drugi su po redu najučestaliji pleuralni izljevi. Oko $75 \%$ pleuralnih malignih izljeva u ljudi uzrokovano je rakom pluća, rakom dojke ili leukemijom (Light, 2011.). U pasa od malignoma $\mathrm{u}$ kojih dolazi do pojave hiloznih pleuralnih izljeva prevladavaju karcinomi i timomi, dok se mezoteliomi i druge vrste tumora rijetko javljaju (Cohn, 2006.). Thompson i Rebar (2016.) navode da su tumori koji dovode do pojave pleuralnog izljeva u pasa limfomi (slika 1.), karcinomi i adenokarcinomi, dok sarkomi i mezoteliomi rijetko dovode do pojave pleuralnog izljeva.

\section{Proteomski pristup pleuralnim izljevima}

Ekstracelularne vezikule su membranske vezikule, substanične strukture omeđene fosfolipidnim 
dvoslojem (Akers i sur., 2013.). Najšire prihvaćene skupine ekstracelularnih vezikula koje su opisane na temelju biogeneze su: egzosomi, mikrovezikule i apoptotska tijela (Thery i sur., 2009.). Ekstracelularne vezikule predstavljaju heterogenu populaciju membranskih vezikula koje otpuštaju normalne, aktivirane i tumorske stanice. Osim veće stope otpuštanja od normalnih stanica, tumorske ekstracelularne vezikule se razlikuju od ekstracelularnih vezikula normalnih stanica i po proteinskom i nukleinskom sastavu (Akers i sur., 2013.).

Tumorske ekstracelularne vezikule prenose različite bioaktivne molekule; od nukleinskih kiselina do metaloproteaza, metabolita i lipida (Maas i sur., 2017., Tricarico i sur., 2017.). Naime, prosječna veličina egzosoma u promjeru iznosi 30-150 nm, dok prosječni promjer prolijevajućih mikrovezikula iznosi 501300 nm (Xu i sur., 2015., Kowal i sur., 2016., Tkach i sur., 2017.).

$\mathrm{U}$ posljednje se vrijeme znatno proširilo znanje o biogenezi, molekularnom sadržaju i horizontalnoj komunikaciji različitih vrsta ekstracelulrnih vezikula. Kao posljedica tih spoznaja, pojavile su se mnoge informacije o sastavu ekstracelularnih vezikula i njihovoj molekularnoj funkciji, zajedno s idejom da se stanice raka služe ovim česticama da bi upadale u tkiva i širile onkogene signale na daljinu (Minciacchi i sur., 2015.).

Dokazano je da ekstracelularne vezikule imaju snažnu ulogu kao posrednici u sepsi. Također je postalo očito da mogu djelovati i kao prijatelji i neprijatelji u sustavnim upalnim reakcijama; njihov prijateljski ili neprijateljski karakter uvelike ovisi o podrijetlu samih ekstracelularnih vezikula i tereta koji oni prevoze (Raeven i sur., 2018.).

Egzosomi kao što su flotilini imaju važnu ulogu u mnogim biološkim procesima poput proliferacije stanica, apoptoze, adhezije i širenja stanica.
Istraživanja pokazuju da su flotilini smješteni na lipidnoj splavi mikrodomene i da su dva proteina uključena u povlačenje vezikula plazmatske membrane (Babuke i sur., 2009.).

Međusobne interakcije flotilina s različitim proteinima i njihov jaki učinak na signalne molekule poput lipidnih splavi proteina omogućuju njihove razne biološke funkcije kod različitih stanica. Mnoga istraživanja pokazuju da su flotilini prekomjerno izraženi kod različitih tumorskih procesa i usko vezani uz razvoj, stupnjevanje i metastaze tumora. Osnovni mehanizmi i uloga flotilina $\mathrm{u}$ razvoju malignih tumora, širenju i metastazama još uvijek nisu u potpunosti razjašnjeni (Liu i sur., 2018.).

Benko i sur. (2019.) preliminarnim istraživanjima pronašli su dokaze da serum i izljev pasa $\mathrm{s}$ malignim oboljenjima, primjerice $\mathrm{s}$ plućnim adenokarcinomima sadrže različite sastave proteina, tj. egzosoma, sa značajno povišenom serumskom koncentracijom flotilina-1, adiponektina i CD63. Buduće analize egzosoma u većoj populaciji ispitivanih pasa mogle bi rezultirati mogućim biomarkerima za rano otkrivanje adenokarcinoma.

\section{Literatura}

1. ALLEMAN, A. R. (2003): Abdominal, thoracic, and pericardial effusions. Vet. Clin. North. Am. Small. Anim. Pract. 33, 89-118.

2. AKERS, J. C., D. GONDA, R. KIM, B. S. CARTER and C. C. CHEN (2013): Biogenesis of extracellular vesicles (EV): exosomes, microvesicles, retrovirus like vesicles, and apoptotic bodies. J. Neurooncol. 113, 1-11.

3. BABUKE, T., M. RUONALA, M. MEISTER, M. AMADDII, C. GENZLER, A. ESPOSITO and R. TIKKANEN (2009): Hetero-oligomerization of reggie-1/flotillin-2 and reggie-2/flotillin-1 is required for their endocytosis. Cell. Signal. 21, $1287-$ 1297.

4. BAKER, R. and J. H. LUMSDEN (2000): Pleuraland peritoneal fluids. In: Baker, R., J. H. Lumsden: Color atlas of cytology of the dog and cat, St. Louis, Mosby, (159-176).

5. BARNHART, M. D. and L. M. RASMUSSEN (1996): Pleural effusion as a complication of extrahepatic 
biliary tract rupture in a dog. J. Am. Anim. Hosp. Assoc. 32, 409-412.

6. BARRS, V. R., G. S. ALLAN, P. MARTIN, J. A. BEATTY and R. MALIK (2005): Feline pyothorax: a retrospective study of 27 cases in Australia. J. Feline Med. Surg. 7, 211-222.

7. BASU, S., S. BHADANI and V. K. SHUKLA (2010): A dangerous pleural effusion. Ann. R. Coll. Surg. Engl. 92, W53-54.

8. BAUER, T. and J. A. WOODFIELD (1995): Mediastinal, pleural and extrapleural diseases. In: Ettinger, S. J., E. C. Feldman: Textbook of veterinary internal medicine, $4^{\text {th }}$ ed., Philladelphia, W.B. Saunders Company, (812-842).

9. BEATTY, J. and V. BARRS (2010): Pleural effusion in the cat: a practical approach to determining aetiology. J. Feline Med. Surg. 12, 693-707.

10. BELLENGER, C. R., C. TRIM and G. SUMMERSMITH (1975): Bile pleuritis in a dog. J. Small. Anim. Pract. 16, 575-577.

11. BENKO, V., A. GALAN COUSILLAS, J. TRŠAN, V. MRLJAK and M. TORTI (2019): Proteomic analysis of pleural effusion and its potential in clinical diagnostic of canine pulmonary adenocarcinoma. $8^{\text {th }}$ International congress Veterinary science and profession (Zagreb, 10.-12. listopada, 2019.). Zbornik sažetaka. Zagreb (ISSN 2706-1795).

12. BEZUIDENHOUT, A. J. (1993): The lymphatic system. In: Evans, H. E., ed. Miller s Anatomy of the $\operatorname{dog} 3^{\text {rd }}$ ed. Philadelphia: WB Saunders, (722-732).

13. BIRCHARD, S. J., M. A. McLOUGHLIN and D. D. SMEAK (1995): Chylothorax in the dog and cat: a review. Lymphology 28, 64-72.

14. BOOTHE, H. W., L. M. HOWE, D. M. BOOTHE, L. A. REYNOLDS and M. CARPENTER (2010): Evaluation of outcomes in dogs treated for pyothorax: 46 cases (1983-2001). J. Am. Vet. Med. Assoc. 236, 657-663.

15. CAROBBI, B., R. A. WHITE and G. ROMANELLI (2008): Treatment of idiopathic chylothorax in 14 dogs by ligation of the thoracic duct and partial pericardiectomy. Vet. Rec. 163, 743-745.

16. CHENG, D., R. M. RODRIGUEZ, E. A. PERKETT, J. ROGERS, G. BIENVENU, U. LAPPALAINEN and R. W. LIGHT (1999): Vascular endothelial growth factor in pleural fluid. Chest. 116, 760-765.

17. COHN, L. A. (2006): Pleural effusion in the dog and cat. International Congress of the Italian Association of Companion Animal Veterinarians, SCIVAC.

18. Da SILVA, C. A. and E. MONNET (2011): Long-term outcome of dogs treated surgically for idiopathic chylothorax: 11 cases (1995-2009). J. Am. Vet. Med. Assoc. 239, 107-113.

19. DAVIS, K. M., and K. A. SPAULDING (2004): Imaging diagnosis: biliopleural fistula in a dog. Vet. Radiol. Ultrasound 45, 70-72.

20. DEMETRIOU, J. L., R. D. FOALE, J. LADLOW, Y. MCGROTTY, J. FAULKNER and B. M. KIRBY (2002): Canine and feline pyothorax: a retrospective study of 50 cases in the UK and Ireland. J. Small. Anim. Pract. 43, 388-394.
21. DEMPSEY, S. M. and P. J. EWING (2011): A review of the pathophysiology, classification, and analysis of canine and feline cavitary effusions. J. Am. Anim. Hosp. Assoc. 47, 1-11.

22. EPSTEIN, S. E. (2014): Exudative pleural diseases in small animals. Vet. Clin. Small. Anim. 44, 161-180.

23. EVANS, H. E. (1993): The respiratory system. In: Evans, H. E.: Miller's anatomy of the dog. Saunders. Philadelphia, (463).

24. FORRESTER, S. D., G. C. TROY and T. W. FOSSUM (1988): Pleural effusions: pathophysiology and diagnostic consideration. Compend. Contin. Educ. Pract. Vet., 121-137.

25. FOSSUM, T. W. (2005): Surgery of the lower respiratory system: pleural cavity and diaphragm. In: Fossum, T. W.: Small animal surgery. St. Louis, Mosby, (788-820).

26. FOSSUM, T. W., S. J. BRICHARD and R. M. JACOBS (1986): Chylothorax in 34 dogs. J. Am. Vet. Med. Assoc. 188, 1315-1318.

27. FOSSUM, T. W. (2000): Pleural and extrapleural disease. In: Ettinger, S. J., E. C. Feldan: Textbook of veterinary internal medicine, $5^{\text {th }}$ ed., W.B. Saunders, Philadelphia, (1098-1111).

28. GUILLAUMIN, J., G. CHANOIT, C. DECOSNEJUNOT and I. GOY-THOLLOT (2006): Bilothorax following cholecystectomy in a dog. J. Small. Anim. Pract. 47, 733-736.

29. HODGES, C. C., T. W. FOSSUM and W. EVERING (1993): Evaluation of thoracic duct healing after experimentall aceration and transection. Vet. Surg. 22, 431-435.

30. HOOFNAGLE, J. H., T. KRESINA, R. K. FULLER, J. R. LAKE, M. R. LUCEY, M. F. SORRELL and T. P. BERESFORD (1997): Liver transplantation for alcoholic liver disease: executive statement and recommendations. Summary of a National Institutes of Health workshop held December 6-7, 1996, Bethesda, Maryland. Liver. Transpl. Surg. 3, 347-350.

31. JANG, S. S., J. E. BREHER, L. A. DABACO and D. C. HIRSH (1997): Organisms isolated from dogs and cats with anaerobic infections and susceptibility to selected antimicrobial agents. J. Am. Vet. Med. Assoc. 210, 1610-1614.

32. JOHNSON, M. S. and M. W. MARTIN (2007): Successful medical treatment of 15 dogs with pyothorax. J. Small. Anim. Pract. 48, 12-16.

33. KOWAL, J., G. ARRAS, M. COLOMBO, M. JOUVE, J. P. MORATH, B. PRIMDAL-BENGTSON, F. DINGLI, D. LOEW, M. TKACH and C. THÉRY (2016): Proteomic comparison defines novel markers to characterize heterogeneous populations of extracellular vesicle subtypes. Proc. Natl. Acad. Sci. USA. 113, E968- E977.

34. KRISTAL, O., K. M. RASSNICK, J. M. GLIATTO, N. C. NORTHRUP, J. D. CHRETIN, K. MORRISONCOLLISTER, S. M. COTTER and A. S. MOORE (2004): Hepatotoxicity associated with CCNU (lomustine) chemotherapyindogs. J. Vet. Intern. Med. 18, 75-80. 
35. LIGHT, R. W. (2011): Pleural effusions. Med. Clin. N. Am. 95, 1055-1070.

36. LIU, X., W. LIU, L. WANG, B. ZHU, X. SHI, Z. PENG, H. ZHU, X. LIU, M. ZHONG, D. XIE, M. ZENG and C. REN (2018): Roles of flotillins in tumors. J. Zhejiang. Univ. Sci. B. 19, 171-182.

37. LÓPEZ, A. and S. A. MARTINSON (2017): Respiratory system, mediastinum, and pleurae. In: Zachary, J. F.: Pathologic basis of veterinary diseases. Elsevier. St. Louis (556).

38. MAAS, S. L. N., X. O. BREAKEFIELD and A. M. WEAWER (2017): Extracellular vesicles: unique intercellular delivery vehicles. Trends. Cell. Biol. 27, 172-188.

39. MAYHEW, P. D., W. T. CULP, K. N. MAYHEW and O. D. MORGAN (2012): Minimally invasive treatment of idiopathic chylothorax in dogs by thoracoscopic thoracic duct ligation and subphrenic pericardiectomy: 6 cases (2007-2010). J. Am. Vet. Med. Assoc. 241, 904-909.

40. MEADOWS, R. L. and P. S. MACWILLIAMS (1994): Chylous effusions revisited. Vet. Clin. Pathol. 23, 54-62.

41. MERTENS, M. M. and T. W. FOSSUM (2002): Pleural and extrapleural diseases. In: Small animal surgery. St. Louis, Mosby (1281-1282)

42. MINCIACCHI, V. R., M. R. FREEMAN and D. D. VIZIO (2015): Extracellular vesicles in cancer: exosomes, microvesicles and the emerging role of large oncosomes. Semin.Cell. Dev. Biol. 40, 41-51.

43. MISEROCCHI, G., D. NEGRINI and J. P. MORTOLA (1984): Comparative feature of Starling-lymphatic interaction at the pleural level in mammals. J. Appl. Physiol. 56, 1151-1156.

44. MURGIA, D. (2013): A caseo of combined bilothorax and bile peritonitis secondary to gunshot wounds in a cat. J. Feline. Med. Surg. 15, 513-516.

45. NAKAMURA, R. K., E. A. ROZANSKI and J. E. RUSH (2008): Non-coagulopathic spontaneous hemothorax in dogs. J. Vet. Emerg. Crit. Care. 18, 292-297.

46. NAMAZI, M. R. and A. MOWLA (2004): Massive right-sided hemorrhagic pleural effusion due to pancreatitis; a casereport. BMC. Pulm. Med. 4, 1- 4.

47. NEATH, P. J., D. J. BROCKMAN and L. G. KING (2000): Lung lobe torsion in dogs: 2 cases (19811999). J. Am. Vet. Med. Assoc. 217, 1041-1044.

48. NELSON, O. L. (2005): Pleural effusion. In: Ettinger, S. J., E. C. Feldman): Textbook of veterinary internal medicine. Elsevier. St. Louis, (204-207).

49. NELSON, R. W. and C. G. COUTO (2014): Clinical manifestation of the pleural cavity and mediastinal diseses. In: Nelson, R. W., C. G. Couto: Small animal internal medicine. Elsevier. St. Louis, (340-341).

50. NOONE, K. E. (1985): Pleural effusions and diseases of the pleura. Vet. Clin. North. Am. Small. Anim. Pract. 15, 1069-1084.

51. O'BRIEN, P. J. and L. H. LUMSDEN (1988): The cytologic examination of body cavity fluids. Semin. Vet. Med. Surg. (Small. Anim.) 3, 140-156.

52. PIEK, C. J. and J. H. ROBBEN (2000): Pyothorax in nine dogs. Vet. Q. 22, 107-111.
53. PRITTIE, J. and L. BARTON (2004): Hemothorax and sanguinous effusions. In: King, L. G.: Textbook of respiratory diseases in dogs and cats. Elsevier. Philadelphia (610-616).

54. RAEVEN, P., J. ZIPPERLE and S. DRECHSLER (2018): Extracellular vesicles as markers and mediators in sepsis. Theranostics 8, 3348-3365.

55. RIZZI, T. E., R. L. COWELL, R. D. TYLER and J. M. MEINKOTH (2008): Effusions: abdominal, thoracic andpericardial. In: Cowell, R. L., R. D. Tyler, J. M. Meinkoth, D. B. DeNicola:Diagnostic cytology and hematology of the dog and cat. MO: Mosby. St. Louis. Pp. 235-255.

56. ROONEY, M. B. and E. MONNET (2002): Medical and surgical treatment of pyothorax in dogs: 26 cases (1991-2001). J. Am. Vet. Med. Assoc. 221, 86-92.

57. SCHULTZ, R. M. and A. ZWINGENBERGER (2008): Radiographic, computed tomographic, and ultrasonographic findings with migrating itra thoracic grassawns in dogs and cats. Vet. Radiol. Ultrasound 49, 249-255.

58. SINGH, A., B. BRISSON and S. NYKAMP (2012): Idiopathic chylothorax in dogs and cats: nonsurgical and surgical management. Compend. Contin. Educ. Vet. 34, E3.

59. SLENSKY, K. (2009): Intraabdominal disorders. Thoracic Trauma. In: Small Animal Critical Care Medicine. Silverstein, D. C., K. Hopper. Elsevier. Pp. 662-667.

60. SONGER, J. G. and K. W. POST (2005): Veterinary microbiology: bacterial and fungal agents of animal disease, St. Louis, Saunders, 10-12, 55-59, 83-86.

61. STOCKHAM, S. L. and M. A. SCOTT (2008): Cavitary effusion. In: Stockham, S. L., M. A. Scott: Fundamentals of veterinary clinical pathology. Ames, Blackwell (831-868).

62. SYKES, J. E. (2012): Actinomycosis and nocardiosis. In: Greene, C. E.: Infectious diseases of the $\operatorname{dog}$ and cat, $4^{\text {th }}$ ed., St.Louis, Elsevier Saunders, 484-520.

63. THÉRY, C., M. OSTROWSKI and E. SEGURA (2009): Membrane vesicles as conveyors of immune responses. Nat. Rev. Immunol. 9, 581-593.

64. THOMPSON, C. A. and A. H. REBAR (2016): Body cavity fluids. In: Raskin, R. E.: Canine and feline cytology. Elsevier: St. Louis, (207-213).

65. TKACH, M., J. KOWAL, A. E. ZUCCHETTI, L. ENSERINK, M. JOUVE, D. LANKAR, M. SAITAKIS, L. MARTIN-LAUAR and C. THERY (2017): Qualitative differences in T-cell activation by dendritic cell-derived extracellular vesicle subtypes. Embo. J. 36, 3012-3028.

66. TRICARICO, C., J. CLANCY and C. D'SOUZASCHOREY (2017): Biology and biogenesis of shed microvesicles. Small. GTPases. 8, 220-232.

67. TYLER, R. D. and R. L. COWELL (1989): Evaluation of pleural and peritoneal effusions. Vet. Clin. North Am. Small. Anim. Pract. 19, 743-768.

68. UCHIKOV, A. P., H. D. SHIPKOV and D. I. MARKOVA (2000): Pleural effusions in acute pancreatitis. Folia. Med. (Plovdiv) 42, 34-36. 
69. WALKER, A. L., S. S. JANG and D. C. HIRSH (2000): Bacteria associated with pyothorax of dogs and cats: 98 cases (1989-1998). J. Am. Vet. Med. Assoc. 216, 359-363.

70. XU, R., D. W. GREENING, A. RAI, H. JI and R. J. SIMPSON (2015): Highly-purified exosomes and shed microvesicles isolated from the human colon cancer cell line LIM1863 by sequential centrifugal ultrafiltration are biochemically and functionally distinct. Methods 87, 11-21.

71. ZOCCHI, L. (2002): Physiology and pathophysiology of pleural fluid turnover. Eur. Respir. J. 20, 1545-1558.

\section{Causes and laboratory diagnostic of pleural effusions in dogs}

Valerija BENKO, DVM, Jadranka FORŠEK, BSc, Vlasta ĐURIĆ, mag. med. biochem., Iva ŠMIT, DVM, PhD, Assistant Professor, Ines JOVIĆ, DVM, PhD, Senior Assistant, Marin TORTI, DVM, PhD, Assistant Professor, Faculty of Veterinary Medicine University of Zagreb, Croatia; Aleksandra RADONJIĆ, mag. med. biochem., Health Centre Krapinsko-zagorska county, Klanjec, Croatia

Pleural effusions are defined as pathologic accumulation of free fluid in the pleural cavity, and in dogs they arise from a variety of inflammatory, systemic, infectious and neoplastic conditions, metabolic disorders, trauma and cardiovascular diseases. Pleural effusions are typically classified as transudates, modified transudates, and exudates. From a pathophysiologic standpoint the accumulation of free fluid can be caused by (1) an increase in hydrostatic pressure (as is the case with congestive heart failure), (2) a decrease in oncotic pressure (i.e. due to hypoproteinemia), (3) increased permeability of the vessel wall (most often as a result of inflammatory reaction) and lymphatic obstruction (most often due to tumor growth). Dogs with pathologic pleural effusions often show heavy breathing (respiratory distress, dyspnea) as the most common clinical sign. Other clinical signs include a crouched, sternal recumbent position with extension of the head and neck, open - mouth breathing, tachypnea, forceful abdominal respiration and cyanosis. Thoracocentesis is used to drain the free fluid, but also to sample pleural effusion, as further laboratory examination is crucial to establish a suspicion and sometimes a definitive diagnosis of the cause or causes that led to the pathological accumulation of fluid in the pleural cavity. The purpose of this review is to present the causes and specific types of effusions in the pleural cavity in dogs, as well as their diagnostic approach.

Key words: pleural effusions; dog; causes; laboratory diagnostic 